\title{
KARAKTERISTIK PLASTIK INDIKATOR SEBAGAI TANDA PERINGATAN DINI TINGKAT KESEGARAN IKAN DALAM KEMASAN PLASTIK
}

\section{Characteristics of Plastic Indicator for Early Warning Indicator of Fish Freshness in a Plastic Packaging}

\author{
Rudi Riyanto ${ }^{1 *}$, Irma Hermana ${ }^{1}$, dan Singgih Wibowo ${ }^{1}$ \\ ${ }^{1}$ Balai Besar Penelitian dan Pengembangan Pengolahan Produk dan Bioteknologi Kelautan dan Perikanan, \\ JI. K.S. Tubun Petamburan VI, Jakarta Pusat, Indonesia \\ * Korespondensi Penulis: r.riyanto76@gmail.com
}

Diterima: 17 November 2014; Disetujui: 2 Desember 2014

\begin{abstract}
ABSTRAK
Tujuan penelitian ini adalah untuk mempelajari karakteristik tanda peringatan dini atau early warning indicators (EWI) yang dibuat dari beberapa jenis indikator $\mathrm{pH}$ untuk mendeteksi kesegaran ikan dalam kemasan plastik. Tiga jenis indikator $\mathrm{pH}$ dan campuran dua indikator $\mathrm{pH}$ digunakan dalam penelitian ini, yaitu bromothymol blue (BTB), bromocresol green (BCG), bromocresol purple (BCP), dan campuran BCG dan methyl red (MR). Sensitivitas masing-masing indikator diuji menggunakan $\mathrm{NH}_{4} \mathrm{OH}$ selama 15 menit dan filet ikan kurisi (Nemipterus nematophorus) selama 15 jam penyimpanan pada suhu ruang. Contoh ikan diambil setiap 3 jam untuk analisis kandungan TVB-N dan jumlah bakteri total (TPC). Hasilnya menunjukkan bahwa indikator BTB memberikan respon lemah terhadap $\mathrm{NH}_{4} \mathrm{OH}$ dan perubahan kesegaran filet ikan. Respon yang lebih baik ditunjukkan oleh BCG, BCP, dan campuran BCG dan MR. Perubahan warna pada indikator tersebut terjadi ketika kandungan TVB-N dan TPC pada filet ikan masing-masing mencapai 33,29 $\pm 4,24 \mathrm{mgN} / 100 \mathrm{~g}$ dan $10^{6} \mathrm{cfu} / \mathrm{gr}$. Perubahan warna dapat dengan mudah dikenali dan diidentifikasi secara visual. Untuk merancang EWI, biaya bahan yang diperlukan untuk membuat indikator kurang penting dibandingkan dengan pertimbangan sensitivitas indikator.
\end{abstract}

KATA KUNCl: $\quad$ plastik indikator, tanda peringatan dini, indikator $\mathrm{pH}$, kesegaran ikan

\begin{abstract}
The objective of the research was to characterize early warning indicators (EWI) made of various $\mathrm{pH}$ indicators for detecting fish freshness in a plastic packaging. Three types of $\mathrm{pH}$ indicator and a mixture of two $\mathrm{pH}$ indicators have been employed. The $\mathrm{pH}$ indicators were bromothymol blue (BTB), bromocresol green (BCG), bromocresol purple (BCP), and mixture of BCG and methyl red (MR). Sensitivity of the indicators were tested against $\mathrm{NH}_{4} \mathrm{OH}$ for 15 minutes and threadfin bream fish (Nemipterus nematophorus) fillet for 15 hours at ambient temperature. Fish sample were taken in every 3 hours for TVB-N and bacterial load analysis. The results showed that BTB indicator showed weak sensitivity in responding $\mathrm{NH}_{4} \mathrm{OH}$ and freshness changes of fish fillet. Better sentifity was shown by BCG, BCP and mixture of BCG and MR. Color changes of the BCG, BCP, and mixture of BCG \& MR occurred when TVB-N level in the fish fillet was $33.29 \pm 4.24 \mathrm{mgN} / 100 \mathrm{~g}$ and bacterial load of $10^{6} \mathrm{cfu} / \mathrm{gr}$. The color change could be easily recognized and identified visually. For designing the EWI, material cost showed less important compared to sensitivity consideration.
\end{abstract}

KEYWORDS: $\quad$ plastic indicator, early warning indicator (EWI), pH indicator, fish freshness

\section{PENDAHULUAN}

Informasi yang diberikan produsen pangan kepada konsumen semakin informatif, lengkap dan mudah dikenali, terutama yang berkaitan dengan keamanan pangan seperti masa kadaluwarsa, tingkat kesegaran produk, dan sebagainya. Informasi tersebut semakin memungkinkan untuk diberikan, terutama karena makin berkembangnya teknologi kemasan cerdas (smart packaging). Kemasan cerdas ini dapat dirancang untuk memberikan informasi aktual mengenai tingkat kesegaran dan keamanan produk 
pangan, termasuk produk perikanan, yang dikemas. Lebih dari itu, kemasan cerdas sekaligus dapat membantu mengurangi risiko kerugian akibat kerusakan produk, dan dapat memberikan estimasi lebih akurat akan kondisi produk dibandingkan label kadaluwarsa konvensional seperti "baik digunakan sebelum tanggal" (Pacquit et al., 2008).

Kemasan cerdas (smart packaging) sering disalahartikan sebagai kemasan aktif (active packaging) yang sebenarnya berbeda, terutama dalam fungsinya (Day, 2003; Robertson, 2006). Kemasan aktif (active packaging) dirancang terutama untuk meningkatkan kemampuan kemasan dalam menjaga aspek mutu dan keamanan produk, sedangkan kemasan cerdas (smart packaging) dirancang dengan dilengkapi indikator, diletakkan internal maupun eksternal, untuk memberikan informasi tentang keadaan atau mutu produk dalam kemasan tersebut. Dengan demikian, kemasan aktif memiliki satu atau beberapa kemampuan dalam hal memerangkap atau menahan masuknya oksigen, menyerap karbondioksida, uap air, etilen, dan atau flavor, noda, mengeluarkan karbondioksida, etanol, antioksidan, serta memelihara kontrol suhu dan bertanggung jawab terhadap perubahan suhu. Sedangkan kemasan cerdas tidak dipersyaratkan sebagai kemasan yang aktif, namun secara pandai mengisyaratkan secara informatif dan jelas dengan menggunakan indikator mengenai kondisi produk yang dikemas.

Ada dua macam indikator yang dapat mendeteksi mutu makanan yang bersifat non-destruktif yakni timetemprature integrators (TTI) dan food quality indicators (FQI). Kedua indikator ini bekerja berdasarkan reaksi kimia yang menghasilkan perubahan warna dan berfungsi sebagai detektor adanya perubahan warna akibat perubahan mutu produk pangan di dalam kemasan, termasuk di dalamnya produk perikanan. Pada TTI (Taoukis et al., 1999; Eskin \& Robinson, 2001; Taoukis et al., 2011), perubahan warna disebabkan karena adanya perubahan suhu yang menyebabkan terjadinya reaksi kimia antara produk dan indikator (perubahan warna). Namun, TTI masih belum dapat menginformasikan mutu produk yang dikemas, terlebih produk hasil perikanan yang proses kemunduran mutunya berjalan kompleks (Eskin \& Robinson, 2001). Pada FQI, perubahan warna terjadi akibat reaksi kimiawi atau biologis yang terjadi di dalam kemasan yang mengindikasikan turunnya mutu atau rusaknya produk yang dikemas (Pacquit et al., 2008; Hubday et al., 2010).

Prinsip kerja FQI pada produk perikanan sebagaimana indikator asam-basa berubah warnanya karena perubahan $\mathrm{pH}$. Untuk produk perikanan, selama proses kemunduran mutu akan terjadi pembentukan senyawa amin yang mudah menguap seperti trimetilamin (TMA), amonia $\left(\mathrm{NH}_{3}\right)$ dan dimetilamin (DMA). Total amin dari senyawa tersebut yang dikenal sebagai total volatile bases nitrogen (TVBN-N) akan meningkat terus dan berkorelasi langsung dengan pola kemunduran mutu (daging) ikan dan bau yang muncul pada ikan setelah melewati fase kesegarannya (Oehlenschlager, 1997).

Basa mudah menguap ini akan terakumulasi dalam kemasan dan menyebabkan perubahan $\mathrm{pH}$ pada sistem kemasan yang pada gilirannya akan terdeteksi oleh indikator melalui perubahan warna (Pacquit et al., 2006). Karena itu, indikator yang digunakan merupakan pewarna indikator $\mathrm{pH}$ dan senyawa indikator tersebut diletakkan di dalam kemasan yang biasanya ditempatkan dalam membran polimer berbasis selulosa (Pacquit et al., 2008). Indikator semacam ini dapat memberikan informasi yang lengkap mulai dari awal terjadinya proses kemunduran mutu ikan yang dengan kata lain dapat dijadikan tanda peringatan dini (early warning indicator atau EWI) bagi mutu produk tersebut. Beberapa jenis indikator yang bekerja berdasarkan perubahan $\mathrm{pH}$ di antaranya adalah bromothymol blue (BTB), bromocresol green (BCG), bromocresol purple (BCP), dan methyl red (MR).

Indikator tersebut di atas akan mengalami perubahan warna dengan adanya perubahan $\mathrm{pH}$. Bromothymol blue (BTB) yang juga dikenal sebagai bromothymol sulfone phthalein merupakan indikator yang bekerja pada asam dan basa lemah. Indikator ini memiliki pH 6 (berwarna kuning) dan $\mathrm{pH} \mathrm{7,6}$ (menjadi biru) dan biasanya digunakan untuk bahanbahan yang relatif netral (sekitar $\mathrm{pH}$ 7). Bromocresol green merupakan pewarna dari kelompok triphenylmethane yang biasanya digunakan sebagai indikator $\mathrm{pH}$ pada medium pertumbuhan mikroorganisme dan untuk titrasi. Indikator ini berwarna kuning di bawah $\mathrm{pH}$ 3,8 dan menjadi biru pada $\mathrm{pH}$ di atas 5,4. Bromocresol purple selain digunakan sebagai plastik $\mathrm{pH}$ juga sering digunakan untuk kepentingan di laboratorium medis untuk mengukur albumin atau untuk kebutuhan prosesing fotografi. Indikator ini akan berwarna kuning pada $\mathrm{pH}$ di bawah 5,2 dan menjadi ungu pada pH di atas 6,8. Methyl red yang juga dikenal sebagai $\mathrm{Cl}$ acid red 2 merupakan indikator $\mathrm{pH}$ yang berubah menjadi merah jika pada suasana asam ( $\mathrm{pH}$ di bawah 4,4) dan menjadi kuning pada suasana basa (pH di atas 6,2).

Sementara itu, untuk menempatkan indikator tersebut diperlukan bahan yang sesuai, seperti misalnya membran polimer berbasis selulosa. Membran polimer berbasis selulosa yang digunakan dapat berupa selulosa-asetat sebagai bahan dasar 
film kemasan yang sekaligus berfungsi sebagai matriks yang mengikat pewarna indikator $\mathrm{pH}$ yang digunakan (Byrne et al., 2002; Pacquit et al., 2005). Selulosa-asetat ini memiliki keistimewaan dalam hal titik lebur (softening point) yang cukup tinggi $\left(230^{\circ} \mathrm{C}\right)$. $\mathrm{Hal}$ ini mengindikasikan bahwa polimer tersebut memiliki ikatan hidrogen intermolekuler dan intramolekuler yang kuat dan dapat dimanfaatkan sebagai bahan dalam pembuatan plastik film yang bersifat biodegradable (Buntyakov \&Aver'yanova, 1969; Hasnedi, 2009). Komposisi kemasan berindikator dengan bahan dasar polimer tersebut di antaranya adalah kitosan-asetat, polivinil alkohol dan indikator warna bromothymol blue (Hasnedi, 2009). Berdasarkan pertimbangan ekonomis dan sifat teknis bahan, selulosa-asetat lebih disarankan untuk digunakan terlebih jika mengingat bahwa selulosaasetat ini dapat diproduksi dari limbah industri rumput laut.

Penelitian ini dilakukan untuk merancang indikator yang dapat digunakan untuk produk perikanan segar dengan mengacu pada prinsip FQI dalam bentuk plastik indikator. Dalam penelitian ini juga dipelajari karakteristik plastik indikator yang dibuat dengan beberapa jenis indikator $\mathrm{pH}$ seperti BTB, BCG, BCP, atau campurannya. Sebagai bahan uji digunakan filet ikan kurisi (Nemipterus nematophorus) yang disimpan pada suhu ruang (sekitar $25-27^{\circ} \mathrm{C}$ ).

\section{BAHAN DAN METODE}

\section{Bahan dan Peralatan}

Bahan yang digunakan untuk membuat plastik indikator adalah plastik berperekat sebagai tempat melekatkan indikator, polimer selulosa asetat, pewarna indikator $\mathrm{pH}$ bromothymol blue (BTB), bromocresol green (BCG), bromocresol purple (BCP), serta campuran bromocresol green (BCG) dan methyl red (MR).

Bahan lain yang digunakan adalah bahan untuk pengujian, yaitu ikan kurisi (Nemipterus nematophorus) dalam bentuk filet yang diperoleh dari tempat pengolahan filet ikan di Tegal, Jawa Tengah. Filet diambil dari tempat pengolahan dalam kemasan kantong plastik dengan bobot $1 \mathrm{~kg}$ per kemasan. Filet dalam kantong plastik dimasukkan ke dalam cool box dengan ditambahkan hancuran es untuk menjaga mutu filet, kemudian diangkut ke ke tempat dilakukan percobaan di Brebes, Jawa Tengah.

Bahan dan peralatan lain yang digunakan adalah bahan dan peralatan yang diperlukan untuk analisis TVBN dan total plate count (TPC).

\section{Metode}

\section{Pembuatan plastik indikator}

Indikator dibuat dari selulosa-asetat (dalam pelarut aseton) dengan pewarna indikator $\mathrm{pH}$ dengan konsentrasi $1 \%$ dalam etanol (BTB, BCG, BCP, campuran BCG dan MR) dengan menggunakan magnetic stirrer (Byrne et al., 2002). Kemudian pH diatur sesuai kisaran $\mathrm{pH}$ aktif. Bahan indikator ini kemudian diteteskan menggunakan pipet tetes (drop pipet) pada plastik berperekat. Setelah kering, indikator dengan plastik berperekat ini ditutup kertas saring (Whatman No.1) dan selanjutnya disebut plastik indikator atau early warning indicator (EWI).

\section{Uji sensitivitas larutan indikator terhadap uap $\mathrm{NH}_{3}$}

Plastik indikator yang masih dalam bentuk larutan diuji sensitivitasnya terhadap gas amin yang terbentuk selama pembusukan ikan. Pengujian sensitivitas ini dilakukan dengan simulasi gas amin dengan uap $\mathrm{NH}_{3}$ dari $\mathrm{NH}_{4} \mathrm{OH}$ yang menguap di dalam wadah tertutup yang kedap. Larutan $1 \mathrm{~N} \mathrm{NH}_{4} \mathrm{OH}(10 \mathrm{ml})$ dan masingmasing larutan indikator (masing-masing $5 \mathrm{ml}$ ) yang diuji ditempatkan dalam wadah terbuka kemudian dimasukkan ke dalam wadah kaca tertutup yang sama (Gambar 1). Dengan cara yang sama, juga dilakukan pengujian sensitivitas plastik indikator yang telah dibuat terhadap uap $\mathrm{NH}_{3}$ dari $\mathrm{NH}_{4} \mathrm{OH}$.

Dengan cara ini, $\mathrm{NH}_{3}$ yang menguap dari $\mathrm{NH}_{4} \mathrm{OH}$ akan tertangkap dan bereaksi dengan larutan indikator yang ada. Jika cukup sensitif, larutan indikator akan bereaksi dengan $\mathrm{NH}_{3}$ dan menyebabkan terjadinya perubahan warna. Pengamatan perubahan warna pada larutan indikator dilakukan setiap menit selama 30 menit.

\section{Uji sensitivitas plastik indikator di lapangan}

Berdasarkan uji sensitivitas terhadap $\mathrm{NH}_{3}$, dilakukan uji sensitivitas plastik indikator di lapangan dengan menggunakan filet ikan kurisi (Nemipterus nematophorus). Uji dilakukan di Brebes, Jawa Tengah menggunakan filet ikan kurisi yang diambil dari UPI filet ikan di Tegal, Jawa Tengah.

Filet ikan kurisi (250 gram) diletakkan di dalam kotak plastik yang kemudian dibungkus plastik pembungkus (plastic wrapper). Plastik indikator ditempatkan terbalik di dalam kemasan dengan ditempelkan pada penutup plastik dengan posisi kertas saring menghadap ke filet ikan (Gambar 2). Di sekeliling wadah ditutup rapat (dengan selotip) untuk mencegah senyawa yang mudah menguap (volatil) hasil perubahan biokimia pada ikan lepas ke luar 


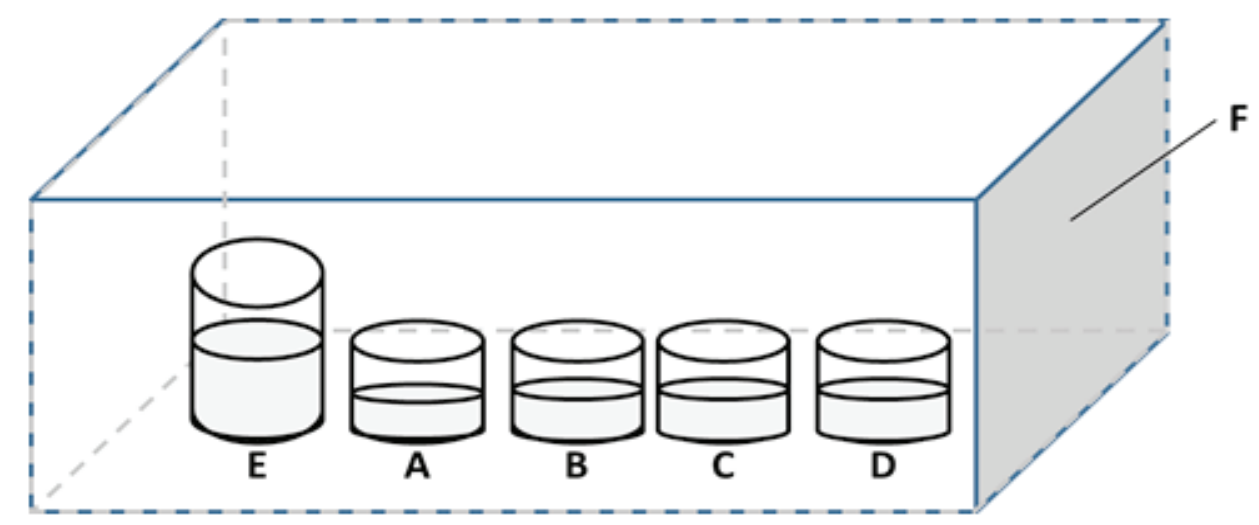

Keterangan/Note: (A) BTB: bromothymol blue; (B) BCG: bromocresol green; (C) BCP: bromocresol purple; (D) campuran BCG \& MR; (E) $10 \mathrm{ml}$ larutan $1 \mathrm{~N} \mathrm{NH}_{4} \mathrm{OH}$; (F) wadah kaca tertutup $100 \mathrm{ml} /$

(A) BTB: bromothymol blue; (B) BCG: bromocresol green; (C) BCP: bromocresol purple; (D) mixture of BCG \& MR; (E) $10 \mathrm{ml}$ of $1 \mathrm{~N} \mathrm{NH}_{4} \mathrm{OH}$ solution; (F) closed glass box $100 \mathrm{ml}$

Gambar 1. Pengujian sensitivitas larutan indikator pH BTB, BCG, BCP, dan campuran BCG dan MR.

Figure. 1. Sensitivity test for $p H$ indicator of $B T B, B C G, B C P$, and mixture of $B C G$ and $M R$.

wadah. Senyawa volatil tersebut akan bereaksi dengan plastik indikator yang menyebabkan terjadinya perubahan warna. Sampel selanjutnya disimpan pada suhu ruang.

Pengamatan dilakukan setiap 3 jam selama 15 jam dengan mengamati adanya perubahan warna yang terjadi pada plastik indikator. Selain perubahan warna, juga dilakukan pengujian kandungan TVBN-N (Apriyantono et al., 1989) dan TPC (Fardiaz, 1992). Pengujian dilakukan dengan 3 kali ulangan.

\section{HASIL DAN PEMBAHASAN}

\section{Pembuatan Plastik Indikator}

Indikator dibuat dengan mencampurkan selulosaasetat (dalam pelarut aseton b/v) dengan pewarna indikator $\mathrm{pH}$, kemudian $\mathrm{pH}$ diatur pada $\mathrm{pH}$ aktifnya, yaitu $\mathrm{pH}$ ketika campuran tersebut memberikan perubahan warna sebagai reaksi terhadap perubahan $\mathrm{pH}$. Karena plastik indikator akan digunakan untuk menangkap senyawa basa yang mudah menguap

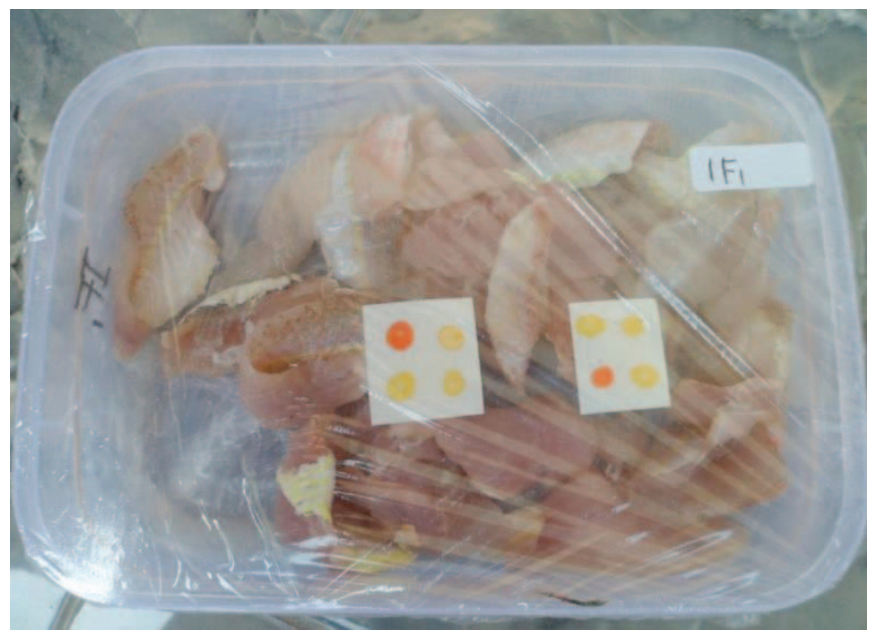

Gambar 2. Pengujian plastik indikator di lapangan dengan menggunakan fillet ikan kurisi (Nemipterus nematophorus).

Figure 2. Field test for plastic indicator using fillet of threadfin bream (Nemipterus nematophorus). 
(basa volatil) yang dihasilkan selama proses kemunduran mutu atau pembusukan ikan, maka $\mathrm{pH}$ diatur menjadi asam sehingga segera menimbulkan perubahan warna ketika bereaksi dengan basa volatil dari ikan.

Hasil menunjukkan bahwa BTB dan BCG mengalami penggumpalan ketika $\mathrm{pH}$ diatur menjadi pH aktifnya, sedangkan BCP dan campuran BCG dengan MR tidak mengalami penggumpalan pada $\mathrm{pH}$ aktifnya. Pada pH asam lemah atau yang lebih basa, selulosa akan menggumpal. Sebaliknya, pada pH yang lebih asam selulosa akan larut dengan baik. Terjadinya penggumpalan ini (pada BTB) akan menyulitkan pencampuran dan pembentukan plastik indikator yang diteteskan dengan menggunakan pipet tetes. Karena itu, pH kemudian diturunkan cukup asam hingga penggumpalan tidak terjadi.

Berdasarkan hasil tersebut, dibuat 4 plastik indikator yaitu Bromothymol Blue (BTB), Bromocresol Green (BCG), Bromocresol Purple (BCP), dan campuran Bromocresol Green (BCG) dengan Methyl Red (MR). Plastik BTB dibuat dengan $\mathrm{pH} 5,0$, plastik $\mathrm{BCG}$ dibuat dengan $\mathrm{pH} 3,8$, plastik $\mathrm{BCP}$ dibuat dengan $\mathrm{pH}$ 5,2 dan campuran plastik BCG dan MR dibuat dengan $\mathrm{pH}$ 5,0. Untuk selanjutnya keempat plastik tersebut diuji sensitivitasnya terhadap senyawa basa volatil yang dihasilkan selama proses kemunduran mutu atau pembusukan ikan. Plastik indikator yang menggunakan BCG, BCP dan BTB berwarna kuning, dan plastik indikator yang menggunakan campuran BCG dan MR berwarna merah (Gambar 3).

\section{Sensitivitas Plastik Indikator terhadap Uap $\mathrm{NH}_{3}$}

Sensitivitas indikator dan plastik indikator diuji secara simulatif terhadap uap $\mathrm{NH}_{3}$ yang dihasilkan dari larutan $\mathrm{NH}_{4} \mathrm{OH}(1 \mathrm{~N})$. Hasil pengujian menunjukkan bahwa perubahan warna pada larutan indikator maupun plastik indikator tidak berbeda. Hasil pengujian sensitivitas plastik indikator seperti dalam Gambar 4.

Dari Gambar 4 tampak bahwa indikator dalam bentuk larutan maupun plastik setelah terpapar uap $\mathrm{NH}_{3}$ dapat memberikan perubahan warna yang cukup jelas sejak menit pertama. Di antara keempat indikator tersebut, 3 indikator memberikan reaksi perubahan warna yang sangat jelas dan mudah dikenali secara visual sejak menit pertama, yaitu BCG (b); BCP (c) dan campuran BCG dan MR (d). Sementara itu, plastik indikator dengan indikator BTB (a) memerlukan waktu lebih lama untuk dapat dikenali secara mudah, yaitu sampai 15 menit untuk dapat membetuk warna kehijauan. Kurang sensitifnya formulasi BTB karena $\mathrm{pH}$ diatur ke $\mathrm{pH} 5$ yang lebih rendah dari $\mathrm{pH}$ aktifnya $(6,0-7,6)$ sehingga diperlukan waktu lebih lama untuk merespon perubahan $\mathrm{pH}$ akibat uap $\mathrm{NH}_{3}$ dari $\mathrm{NH}_{4} \mathrm{OH}$.

\section{Sensitivitas Plastik Indikator terhadap Filet Ikan Kurisi (Nemipterus nematophorus)}

Sensitivitas plastik indikator diuji di lapangan menggunakan filet ikan kurisi yang disimpan selama 15 jam. Selama penyimpanan tersebut juga diamati

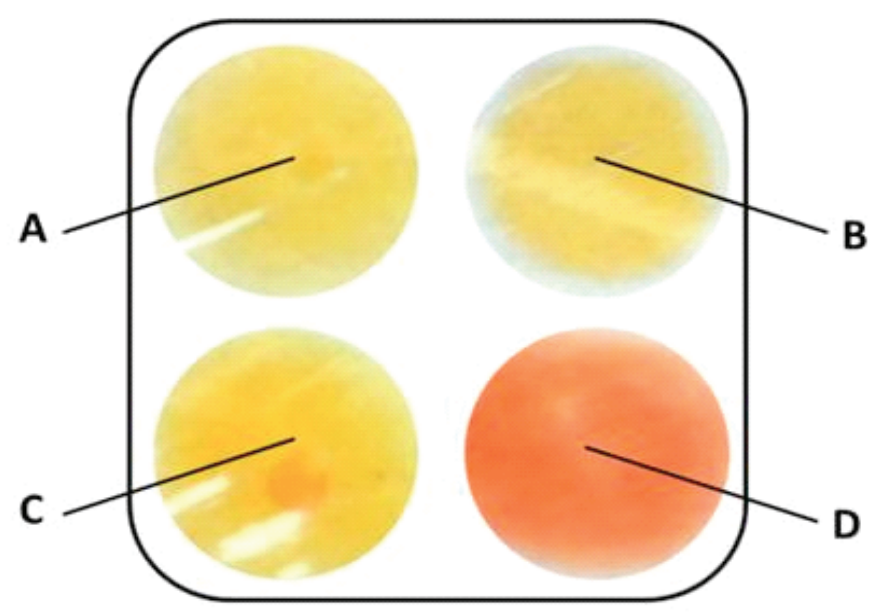

Keterangan/Note: (A) BTB: bromothymol blue; (B) BCG: bromocresol green; (C) BCP: bromocresol purple; (D) campuran BCG dan MR/

(A) BTB: bromothymol blue; (B) BCG: bromocresol green; (C) BCP: bromocresol purple; (D) mixture of $B C G$ and $M R$

Gambar 3. Susunan plastik indikator yang digunakan dalam percobaan.

Figure 3. Posistion of plastic indicator used in the experiment. 


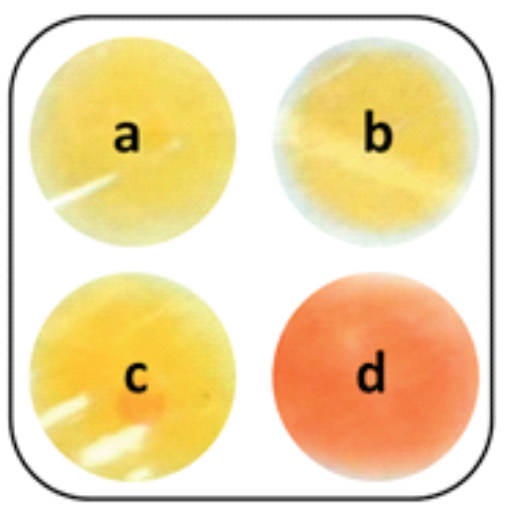

A

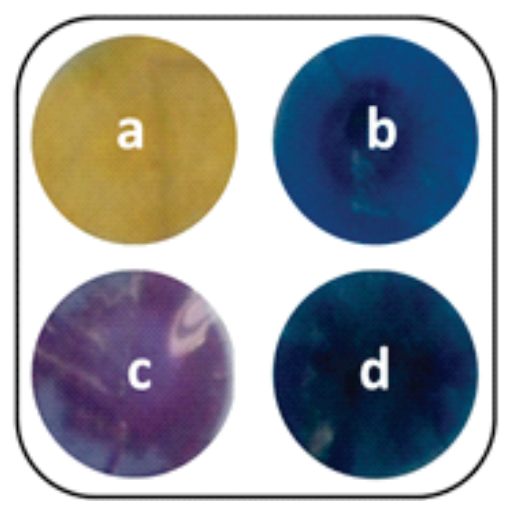

B

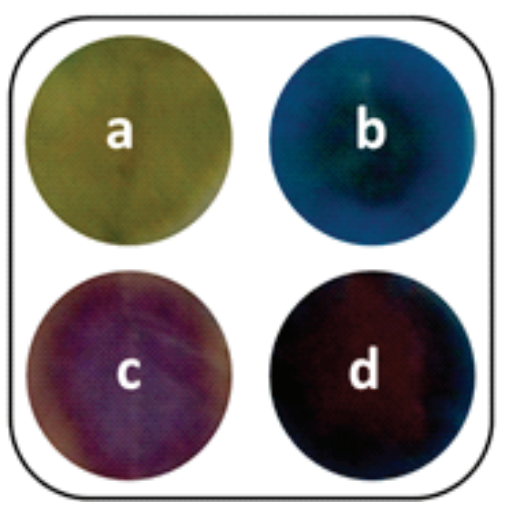

C

Gambar 4. Perubahan warna plastik indikator (a) BTB; (b) BCG; (c) BCP; dan (d) campuran BCG dan MR pada (A) awal sebelum terpapar uap $\mathrm{NH}_{3}$, (B) setelah terpapar uap $\mathrm{NH}_{3}$ selama 1 menit; (C) setelah terpapar $\mathrm{NH}_{3}$ selama 15 menit.

Figure 4. Color change of plastic indicator of (a) BTB; (b) BCG; (c) BCP; and (d) mixture of BCG and MR (A) before exposure with $\mathrm{NH}_{3}$, (B) after 1 minute exposure with $\mathrm{NH}_{3}$; (C) after 15 minutes exposure with $\mathrm{NH}_{3 .}$

perkembangan kandungan TVB-N dan TPC seperti tampak pada Gambar 5 dan 6. Sedangkan perubahan warna plastik indikator tampak pada Gambar 7. Dari Gambar 5 dan 6 tampak bahwa pada awal penyimpanan, kandungan TVB-N dan TPC pada filet ikan kurisi sudah cukup tinggi, yaitu masing-masing $25,28 \pm 1,13 \mathrm{mgN} / 100 \mathrm{~g}$ dan lebih dari $10^{4} \mathrm{cfu} / \mathrm{g}$. Untuk ukuran ikan segar (yang dies) jumlah ini telah melewati batas kesegaran ikan dan dapat dikatagorikan masuk dalam tahap pembusukan.

Kandungan TVB-N tampak meningkat tajam pada jam ke 3 dan 6 dan relatif konstan pada jam penyimpanan selanjutnya (Gambar 5). Perkembangan kandungan TVB-N ini sejalan dengan perkembangan

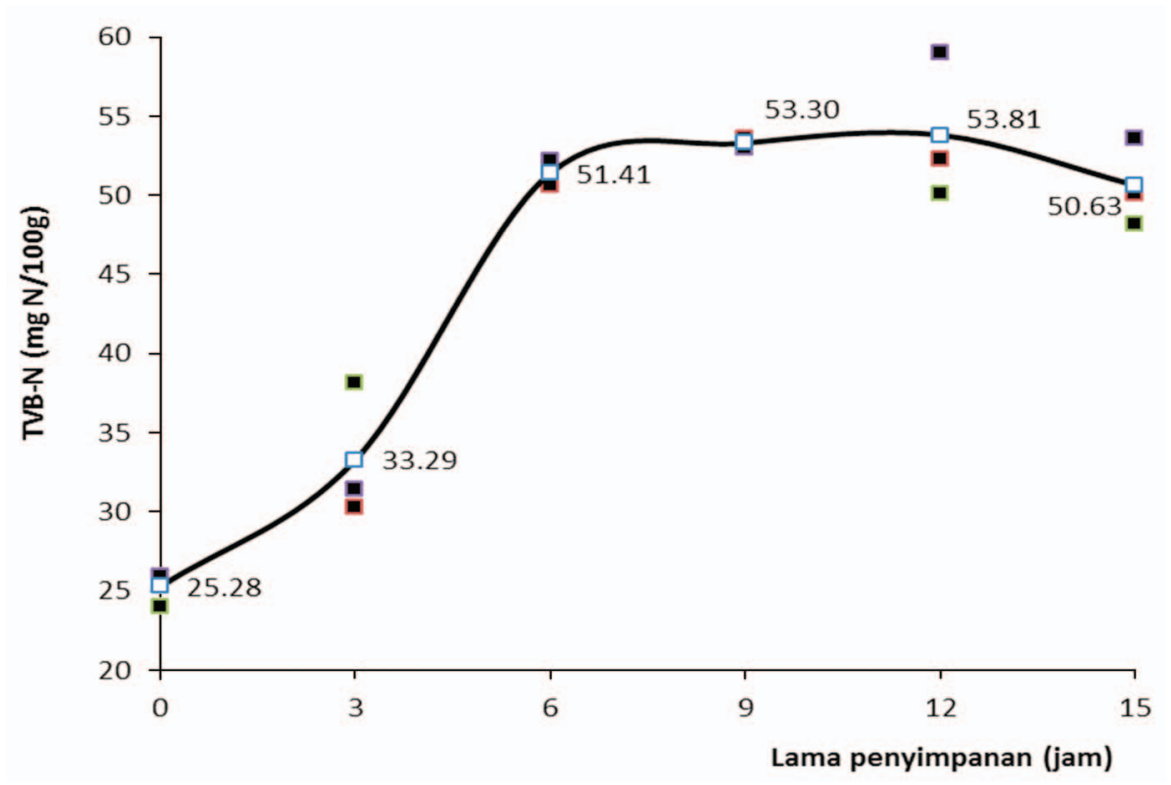

Gambar 5. Perkembangan kandungan TVB-N pada fillet ikan kurisi selama penyimpanan (rata-rata dari 3 ulangan).

Figure 5. Development of TVB-N content in threadfin bream fillet (Nemipterus nematoph orus) during storage (average of 3 replications). 


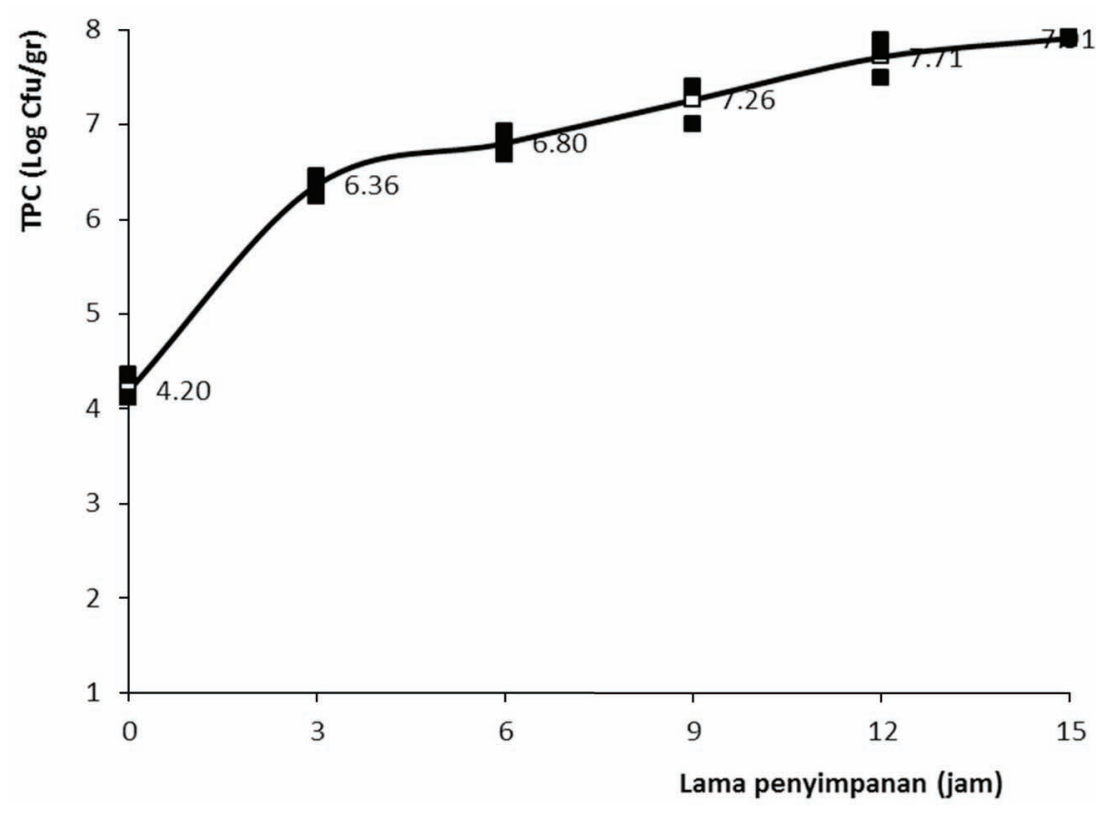

Gambar 6. Perkembangan kandungan TPC pada fillet ikan kurisi selama penyimpanan (rata-rata dari 3 ulangan).

Figure. 6. Development of TPC content in threadfin bream fillet (Nemipterus nematophorus) during storage (average of 3 replications).

kandungan bakteri total (TPC) sebagaimana tampak pada Gambar 6. Pada jam ke 3 kandungan TVB-N mencapai 33,29 $\pm 4,24 \mathrm{mgN} / 100 \mathrm{~g}$ dan meningkat tajam pada jam ke 6 mencapai 51,41 $\pm 0,80 \mathrm{mgN} /$ $100 \mathrm{~g}$. Pada saat yang sama kandungan bakteri total telah mencapai lebih dari $10^{6} \mathrm{cfu} / \mathrm{g}$ pada jam ke 3 dan hampir $10^{7} \mathrm{cfu} / \mathrm{g}$ pada jam ke 6 (Gambar 6).

Senyawa TVB-N merupakan hasil dekomposisi protein oleh aktivitas bakteri dan enzim menghasilkan hingga $95 \%$ amonia dan $\mathrm{CO}_{2}$. Senyawa yang terbentuk sebagai hasil dekompoisi protein tersebut merupakan senyawa yang mengandung nitrogen yang bersifat basa dan volatil (basa volatil) yang keseluruhanya dinyatakan sebagai Total Volatile Bases (TVB-N) (Alasalvar, 2002). Senyawa hasil dekomposisi protein yang bersifat volatil adalah amonia, $\mathrm{H}_{2} \mathrm{~S}$, merkaptan, fenol, kresol, indol dan skatol yang merupakan basa volatil dan menyebabkan peningkatan $\mathrm{pH}$ serta menimbulkan bau busuk. Di samping itu, akibat langsung dari dekomposisi protein akan menyebabkan total $\mathrm{N}$ non-protein meningkat dan ikan menjadi bersifat lebih basa dengan $\mathrm{pH}$ 7,1 - 7,2.

Kondisi ini mengindikasikan bahwa proses pembusukan telah berjalan dengan intensif dan terjadi pembentukan basa-basa mudah menguap yang akan bereaksi dengan plastik indikator dan menyebabkan terjadinya perubahan warna pada plastik indikator (Gambar 7). Perubahan warna tersebut tampak jelas dan mudah dikenali secara visual pada plastik indikator BCG, BCP dan campuran BCG dan MR, namun belum tampak direspon dengan cepat oleh plastik indikator BTB. Hasil ini sejalan dengan hasil uji sensitivitas menggunakan $\mathrm{NH}_{4} \mathrm{OH}$ (Gambar 4).

Pada plastik indikator BTB meskipun telah terjadi perubahan tetapi perubahan tersebut secara visual tidak mudah dikenali dengan baik hingga 12 jam penyimpanan, dan bahkan masih sulit dikenali setelah 15 jam penyimpanan yaitu dari berwarna kuning menjadi kuning sedikit kehijauan pada jam ke 12 dan kuning agak gelap pada jam ke 15 . Sementara, pada saat yang sama kandungan TVB-N sudah tinggi, yaitu pada jam ke 12 mencapai $53,81 \mathrm{mgN} / 100 \mathrm{~g}$ yang telah mengindikasikan bahwa ikan telah mengalami proses pembusukan. Ini berarti bahwa plastik indikator BTB sangat lemah dalam mendeteksi perubahan $\mathrm{pH}$ sehingga tidak cukup sensitif untuk menunjukkan proses pembusukan yang terjadi.

Sebaliknya, plastik indikator BCG, BCP dan campuran BCG dan MR memberikan respon yang jelas dan perubahan warna dapat dikenali secara visual dengan baik sejak jam ke 3 penyimpanan. Plastik indikator BCG pada jam ke 3 berubah warna dari kuning ke hijau kekuningan dan menjadi biru pekat pada jam ke 15. Akan tetapi, perubahan warna pada jam ke 3 dan ke 6 sulit untuk dibedakan meskipun perubahan kandungan TVB-N ikan cukup tinggi. Hal serupa juga terjadi pada plastik indikator BCP yang berubah dari kuning menjadi kuning kecoklatan pada 


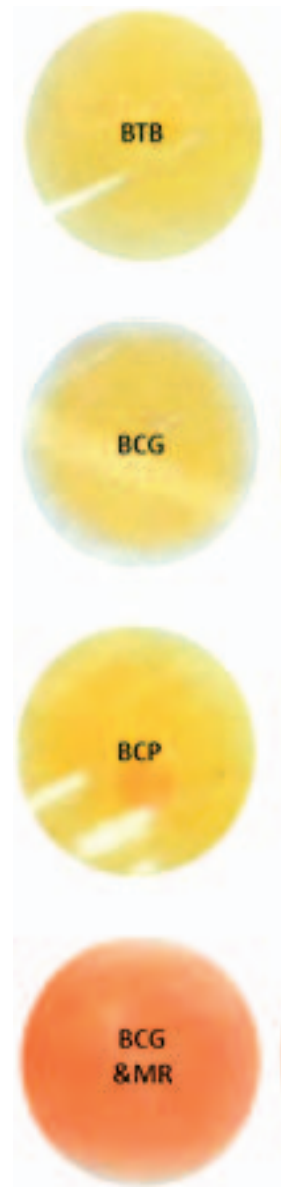

A
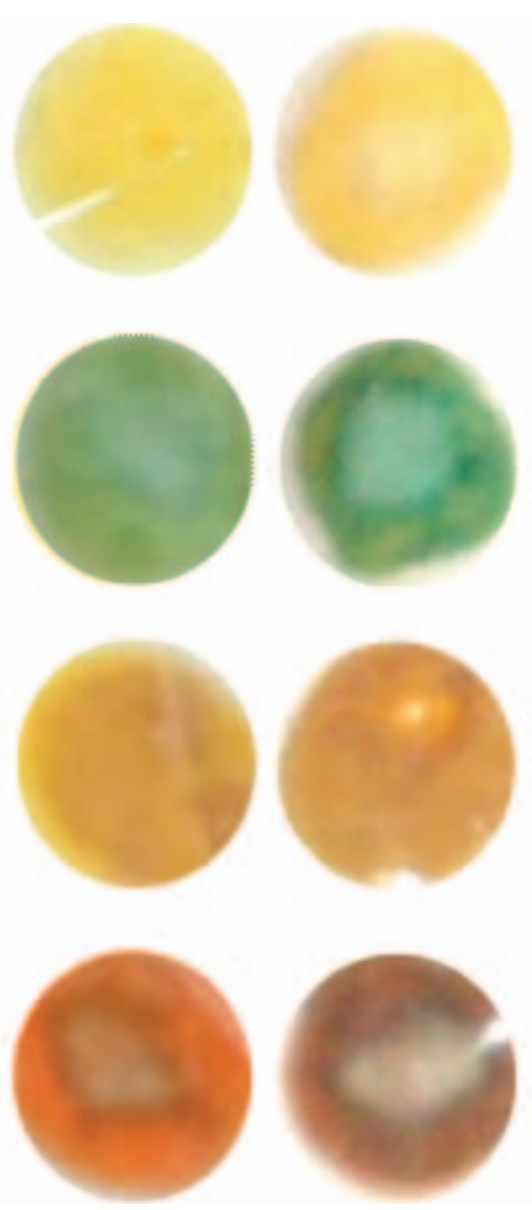

B
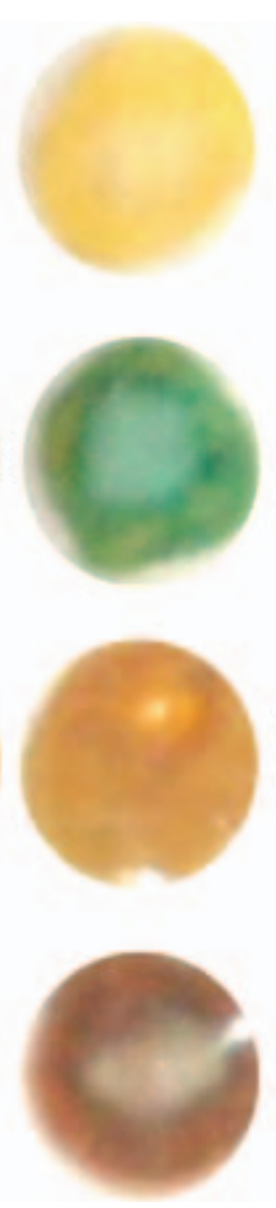

C
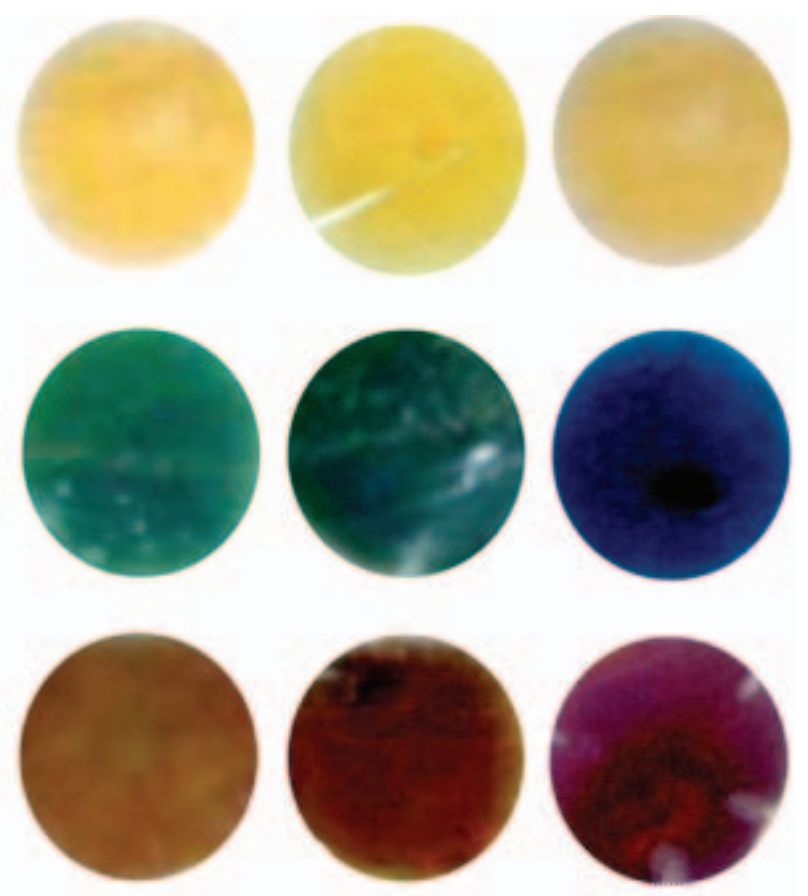

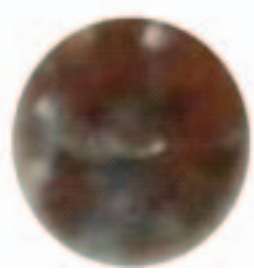

$\mathrm{D}$

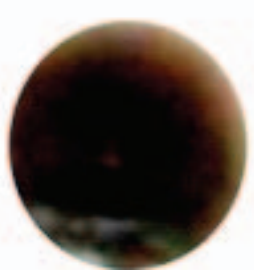

E

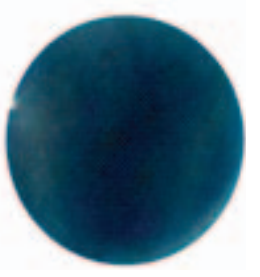

$\mathrm{F}$

Gambar 7. Perubahan warna plastik indikator selama penyimpanan filet ikan kurisi (Nemipterus nematophorus) pada (A) 0 jam; (B) 3 jam; (C) 6 jam; (D) 9 jam; (E) 12 jam; dan (F) 15 jam.

Figure. 7. Color change of plastic indicator during storage of threadfin bream (Nemipterus nematophorus) for (A) 0 hour; (B) 3 hours; (C) 6 hours; (D) 9 hours; (E) 12 hours; and (F) 15 hours.

jam 3 dan coklat keunguan pada jam ke 15. Namun, perubahan warna pada jam ke 3 dan ke 6 sulit dibedakan. Perubahan yang bertahap dengan tahapan yang jelas terjadi pada plastik indikator campuran BCG dan MR, yaitu dari merah cerah menjadi coklat kemerahan dan secara bertahap berubah menjadi lebih coklat pada jam ke 6, 9 dan 12 serta menjadi kebiruan pada jam ke 15. Terlepas dari perubahan warna yang kecil antara jam ke 3 dan 6, tampaknya ketiga indikator tersebut mengalami perubahan warna yang sangat jelas dan mudah dikenali secara visual. Ini berarti bahwa plastik indikator tersebut (BCG, BCP, dan campuran BCG dan MR) cukup sensitif untuk mendeteksi proses perubahan atau proses pembusukan ikan yang terjadi.

Pada jam ke 3 ketika kandungan TVB-N sebesar $33,29 \pm 4,24 \mathrm{mgN} / 100 \mathrm{~g}$ dan pada jam ke 6 ketika TVB-N mencapai 51,41 $\pm 0,80 \mathrm{mgN} / 100 \mathrm{~g}$ menandakan bahwa ikan telah tidak segar atau mengalami proses pembusukan. Pada saat tersebut warna plastik indikator BCG telah berubah dari kuning menjadi hijau dengan sedikit warna kuning. Perubahan dari segar menjadi tidak segar dapat ditandai dari perubahan warna dari kuning menjadi biru. Adanya warna kuning pada plastik indikator dapat digunakan untuk menunjukkan masih adanya faktor kesegaran. Makin banyak warna kuning menunjukkan ikan makin segar. Sebaliknya, makin biru warna plastik indikator menunjukkan ikan makin tidak segar. Dengan kata lain, munculnya warna hijau pada plastik indikator BCG menunjukkan mulai berkurang dan hilangnya kesegaran ikan. Untuk plastik indikator BCP, sama seperti BCG, kesegaran ikan dapat diindikasikan dengan warna kuning. Munculnya warna coklat pada plastik indikator BCP menandakan bahwa ikan sudah mulai kurang segar atau kehilangan kesegaran. Untuk 


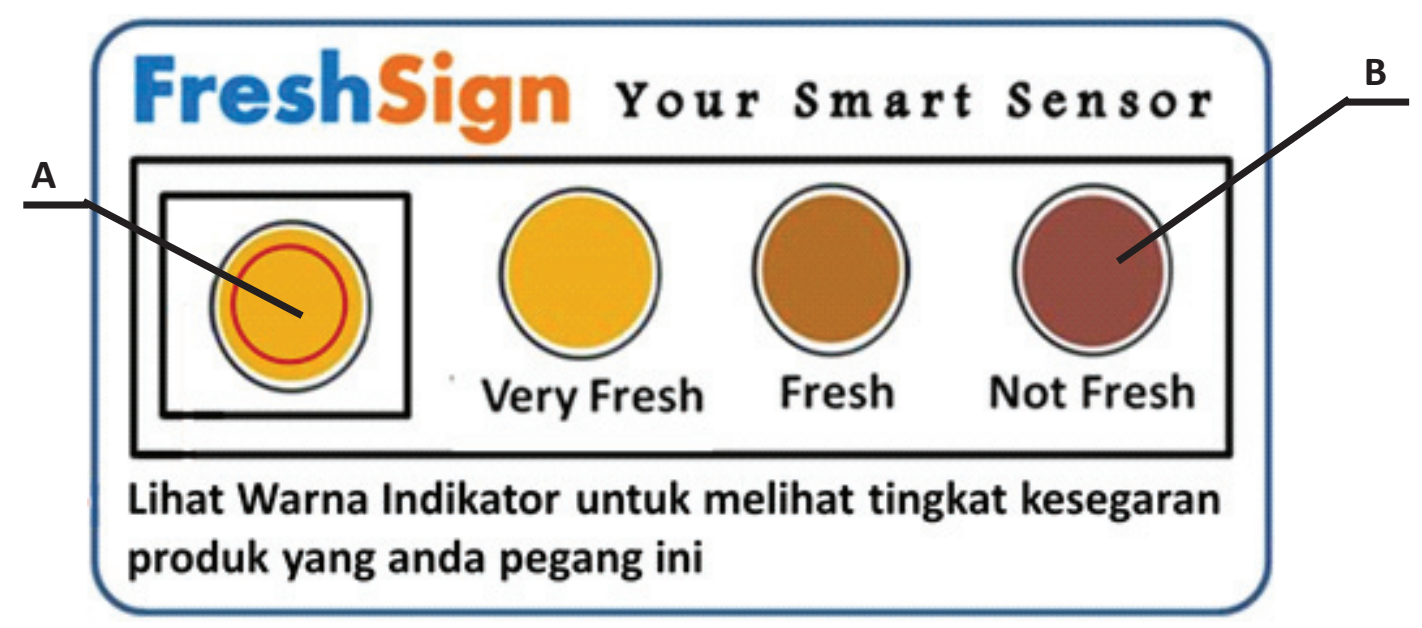

Gambar 8. Bentuk rancangan dasar plastik indikator "FreshSign"; (A) penempatan plastik indikator, (B) keterangan perubahan warna.

Figure 8. Basic design for plastic indicator "FreshSign"; (A) platic indicator location, (B) color change notification.

plastik indikator BCP, warna coklat menjadi penanda tidak segarnya ikan. Untuk plastik indikator BCG dan $\mathrm{MR}$, kesegaran ikan diindikasikan oleh warna indikator yang merah cerah. Munculnya warna coklat menandakan mulai terjadinya proses pembusukan.

\section{Rancangan Plastik Indikator}

Berdasarkan hasil tersebut di atas maka dapat disimpulkan bahwa BTB bukan indikator yang baik untuk menunjukkan tingkat kesegaran ikan. Perubahan kesegaran ikan tidak dapat dideteksi dengan baik oleh BTB. Untuk plastik indikator BCG dan BCP, kesegaran ikan diindikasikan oleh warna kuning sedangkan untuk plastik indikator BCG dan MK diindikasikan oleh warna merah cerah. Hilangnya kesegaran ikan akan ditunjukkan oleh adanya warna hijau pada plastik indikator BCG, dan warna coklat pada plastik indikator BCP dan campuran BCG dan MR. Berdasarkan hasil ini maka dapat dirancang plastik indikator dengan gradasi warna sesuai jenis indikatornya. Bentuk dasar rancangan plastik indikator (FreshSign) seperti dalam Gambar 8. Berdasarkan rancangan dasar tersebut maka dapat dibuat 3 rancangan plastik indikator untuk BCG, BCP dan campuran BCG dan MR seperti pada Gambar 9.

Dengan menggunakan perhitungan sederhana, dapat dihitung biaya yang diperlukan untuk menghasilkan plastik indikator. Biaya bahan yang diperlukan untuk menghasilkan satu plastik indikator tidak besar. Untuk indikator BCG diperlukan biaya sekitar Rp. 110,82/tetes, untuk BCP Rp. 110,34/tetes dan untuk campuran BCG\&MR Rp. 111,85/tetes. Dilihat dari biaya tersebut, tidak tampak ada perbedaan biaya yang besar di antara ke tiga indikator. Hal ini menunjukkan bahwa pertimbangan biaya untuk menghasilkan plastik indikator tidak memberikan pengaruh yang besar untuk pengambilan keputusan memilih jenis indikator yang akan digunakan. Pertimbangan yang diperlukan adalah pertimbangan teknis, terutama kemudahan pengguna atau konsumen untuk mengenali perubahan warna yang terjadi yang berarti berkaitan dengan sensitivitasnya. Berdasarkan sensitivitas tersebut maka plastik indikator BCG mampu merespon dengan baik perubahan $\mathrm{pH}$ yang terjadi dalam kemasan dan perubahan warna yang terbentuk dapat dikenali secara visual dengan mudah dan jelas. Pilihan berikutnya adalah campuran BCP dan MR, dan terakhir adalah BCP.

\section{KESIMPULAN}

Plastik indikator BTB tidak memiliki sensitivitas yang cukup untuk merespon perubahan mutu filet ikan kurisi. Berdasarkan kemudahan pengenalan perubahan warnanya, plastik indikator yang memiliki respon yang sensitif dalam merespon perubahan mutu filet ikan kurisi secara berturut-turut mulai dari yang paling sensitif adalah bromocresol green (BCG), campuran bromocresol green (BCG) dengan methyl red (MR), dan bromocresol purple (BCP). Perubahan warna pada plastik indikator sudah terjadi ketika nilai TVB-N filet ikan kurisi mencapai 33,29 $\pm 4,24 \mathrm{mgN} /$ $100 \mathrm{~g}$ dan nilai TPC $10^{6} \mathrm{cfu} / \mathrm{gr}$.

Peranan biaya produksi per tetes campuran indikator tidak cukup besar untuk menentukan 


\section{FreshSign your smart Sensor}

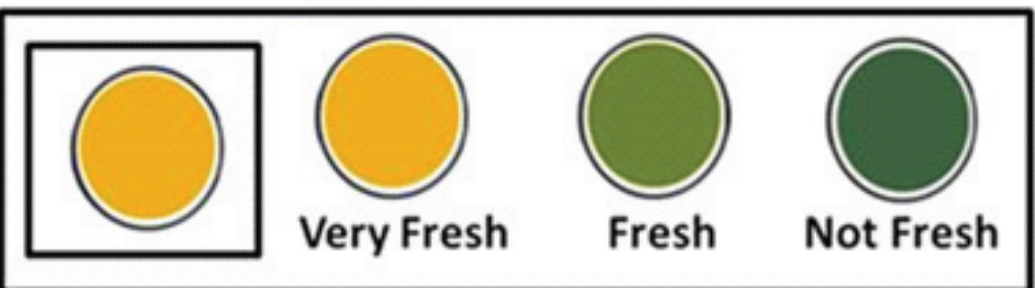

Lihat Warna Indikator untuk melihat tingkat kesegaran produk yang anda pegang ini

A

\section{FreshSign your smart sensor}

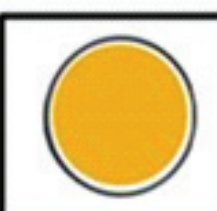

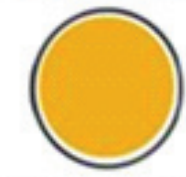

Very Fresh

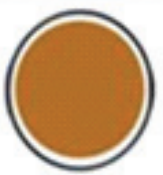

Fresh

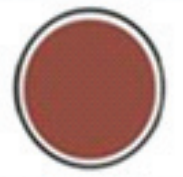

Not Fresh

Lihat Warna Indikator untuk melihat tingkat kesegaran produk yang anda pegang ini

B

\section{FreshSign your smart sensor}

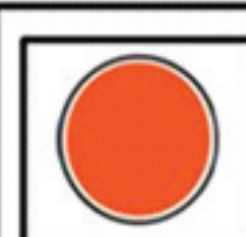

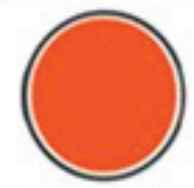

Very Fresh

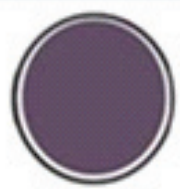

Fresh

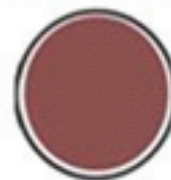

Not Fresh

Lihat Warna Indikator untuk melihat tingkat kesegaran produk yang anda pegang ini

C

Gambar 9. Bentuk rancangan plastik indikator "FreshSign" menggunakan indikator (A) BCG, (B) BCP, dan (C) campuran BCG dan MR.

Figure 9. Design for plastic indicator "FreshSign" using indicator $(A) B C G,(B) B C P$ and $(C)$ mixture of BCG dan MR. 
rancangan plastik indikator. Hal yang sangat diperlukan dalam memutuskan rancangan plastik indikator yang akan digunakan adalah tingkat sensitivitas plastik indikator.

\section{DAFTAR PUSTAKA}

Alasalvar, C. (2002). Seafoods-Quality, Technology, and Nutraceutical Applications. Springer-Verlag, New York. pp. 125-135, 157-170

Apriyantono, A., Fardiaz, D., Puspitasari, N.L., Sedarnawati, \& Budiyanto, S. (1989). Petunjuk Laboratorium Analisis Pangan. Pusat Antar Universitas Pangan dan Gizi Institut Pertanian Bogor, Bogor.

Buntyakov, A.S. \& Aver'yanova, V.M. (1969). Thermal transformations in cellulose acetates. J. Thermal. 34: 1035-1040.

Byrne, L., Lau, K.T., \& Diamond, D. (2002). Monitoring of headspace total volatile basic nitrogen from selected fish species using reflectance spectroscopic measurements of $\mathrm{pH}$ sensitive films. Analyst. 127: 1338-1341.

Day, B.P.F. (2003). Active packaging. In Coles R, McDowell, D. \& Kirwan, M. (eds.). Food Packaging Technologies. CRC Press, Boca Raton, USA. 282$302 \mathrm{p}$.

Eskin, N.A.M. \& Robinson, D.S. (2001). Food Shelf Life Stability: Chemical, Biochemical, Microbiological Changes. CRC Press, Washington DC.

Fardiaz, S. (1992). Mikrobiologi Pangan I. PT. Gramedia Pustaka Utama. Jakarta. 320 pp.

Hasnedi, Y.W. (2009). Pengembangan Kemasan Cerdas (smart packaging) dengan Indikator Berbahan Dasar Chitosan-Asetat, Polivinil Alkohol, dan Pewarna Indikator Bromothymol Blue sebagai Pendeteksi Kebusukan Fillet Ikan Nila. Skripsi. Fakultas Perikanan dan Ilmu Kelautan. Institut Pertanian Bogor, Bogor.
Hubday, D., Higson, S.P.J., \& Mena, C. (2010). Role of diagnostic packaging in food supply chain management. In Mena, C. and Stevens, G. (eds.). Delivering Performance in Food Supply Chains. Woodhead Publishing Ltd. and CRC Press LLC, USA.

Oehlenschlager, J. (1997). Volatile amines as freshness/ spoilage indicators: a literature review. In Luten, J.B., Borresen, T., \& Oehlenschlager, J. (eds.). Seafood from Producer to Consumer, Integrated Approach to Quality: 25th WEFTA International Seafood Conference. Elsevier Science B.V., Amsterdam, The Netherlands 38: 571-586.

Pacquit, A., Lau, K.T., McLaughlin, H., Frisby, J., Quilty, B. \& Diamond, D. (2005). Development of a volatile amine indikator for the monitoring of fish spoilage, Talanta. 69: 515-520.

Pacquit, A., Lau, K. T., McLaughlin, H., Frisby, J., Quilty, B., \& Diamond, D. (2006). Development of a volatile amine sensor for the monitoring of fish spoilage. Talanta. 69: 515-520.

Pacquit, A., Crowley, K., \& Diamond, D. (2008). Smart packaging technologies for fish and seafood products. In Willey John (ed.). Smart Packaging Technologies for Fast Moving Consumer Goods. John Wiley \& Sons Ltd, England. 75-96 p.

Robertson, G.L. (2006). Food Packaging-Principles and Practice. Second edition, CRC Press, Boca Raton, FL, USA.

Taoukis, P.S., Koutsoumanis, K., \& Nychas, G.J.E. (1999). Use of time-temperature integrators and predictive modelling for shelf life control of chilled fish under dynamic storage conditions. International Journal of Food Microbiology. 53: 21-31.

Taoukis, P.S., Tsironi, Th., Giannoglou, M., Metaxa, I., \& Gogou, E. (2011). Historical Review and State of The Art in Time Temperature Integrator (TTI) Technology for The Management of The Cold Chain of Refrigerated and Frozen Foods. Laboratory of Food Chemistry \& Technology, School of Chemical Engineering, National Technical University of Athens. 